\title{
В.Ю. Світлична
}

Харківський національний університет міського господарства імені О.М. Бекетова, Украӥна

\section{ТУРИСТИЧНА СФЕРА: ПОШУК ШЛЯХІВ ПОДОЛАННЯ КРИЗИ В УМОВАХ ГЛОБАЛЬНИХ КАРАНТИННИХ ОБМЕЖЕНЬ}

Досліджуються питання сучасних аспектів функиіонування туристичної сфери країни. Визначаються існуючі проблеми розвитку підприємств туристичної сфери, обумовлені негативним впливом розгортання карантинних обмежень. Увагу скониентровано на дослідженні та розробиі напрямів подолання кризових явищ для підприємств туристичної сфери та досягнення ними сталого функиіонування.

Ключові слова: туризм, туристичні потоки, карантинні обмеження, епідемічні ризики, пандемія, Covid-19, Дорожня карта конкурентоспроможного розвитку сфери туризму в Украйні, розвиток туристичної сфери.

\section{Постановка проблеми та аналіз останніх досліджень і публікацій}

Туризм виступає важливою складовою інфраструктури кожної країни. Адже туристичні підприємства і організації функціонують у тісній співпраці з іншими видами економічної діяльності, забезпечуючи підвищення зайнятості населення. Це, у свою чергу, розвиває позитивний імідж привабливість країни як сфери підприємництва i ділової співпраці, сприяе стійкому економічному зростанню у довгостроковій перспективі, залученню іноземних інвестицій в економіку, зміцненню дохідної частини державного бюджету, покращенню платіжного балансу країни, а отже і добробуту населення.

Розгортання у глобальному масштабі пандемії коронавірусу справило негативний вплив на всі сфери життя людства. В тому числі і на успішне функціонування сфери туризму і гостинності.

Як наслідок, вивчення теоретичних і практичних питань стабілізації функціонування ринку туристичних послуг, запобігання негативного впливу карантинних обмежень та подальшого забезпечення стійкості діяльності підприємств туристичної сфери $\epsilon$ не просто актуальним, багатогранним та комплексним, а висувається в розряд першочергових завдань у сучасних динамічних змінах економічного середовища.

\section{Аналіз останніх досліджень і публікацій}

Різноманітні теоретичні аспекти діяльності туристичної сфери висвітлено у працях таких учених, як: Ворошилова Г.О., ГобликМаркович Н.М., Горіна Г.О., Жаліло Я.А., Заворуєва О.С., Оболенцева Л.В., Шацька З.Я. та інші $[1-6 ; 11 ; 14]$. Однак сьогодні окремі питання щодо подолання негативних явищ підприємствами туристичної сфери i досі залишаються невирішеними та потребують детального вивчення.

\section{Мета статті}

Зважаючи на викладене вище, метою роботи виступає дослідження питань стабілізації функціонування підприємств туристичної сфери в умовах карантинних обмежень.

\section{Виклад основного матеріалу}

Як відомо, туристична сфера вважається однією 3 найбільших динамічних індустрій у світовій економіці та міжнародній торгівлі послугами.

Представляючи собою економічну діяльність, пов'язану із пересуванням людини за межі постійного місця проживання, iї відпочинку із зміцненням здоров'я, підвищенням рівня культури й освіти, туризм об'єктивно придбав значення найбільш розвинутої галузі у глобальному масштабі. Структуру туристичної галузі складають суб'єкти господарювання, які, використовуючи наявний природно-рекреаційний потенціал, надають послуги гостинності, транспортні послуги, та які створюють комплексний туристичний продукт і організовують його споживання (туроператори і турагенції). А умовами ефективного функціонування туристичних підприємств $є$ організація ними комфортного та якісного забезпечення мотиваційних вимог туриста.

За оцінками фахівців: «Міжнародний туризм входить до трійки найбільших галузей-експортерів, поступаючись лише нафтовій промисловості та автомобіле-будуванню, частка яких у світовому експорті становить $11 \%$ та $8,6 \%$, відповідно. Сьогодні туризм $\epsilon$ найбільш розвинутої галузі економіки. Частка туризму перевищує $10 \%$ світової 
торгівлі послугами. Близько 12\% світового валового продукту припадає на туризм, порівняно із 7\% міжнародних інвестицій. Понад 260 млн осіб у світі (приблизно 10\% всіх працюючих) зайнято у сфері туристичних послуг» [7, С. 252]. Підприємства туристичної сфери пов'язані із активним розвитком підприємств готельно-ресторанного бізнесу, торгівельних підприємств, а також сприяють виникненню нових сфер економічної діяльності, які надають послуги i виконують роботи для туристичної індустрії, що, у свою чергу, забезпечує зростання доходів, зайнятості і добробуту населення. Вважаємо за необхідне підкреслити, що туризм стимулює функціонування опосередковано зв'язаних 3 ним сфер діяльності, так витрати, здійснювані туристами під час подорожі становляться доходами суб'єктів, які надають товари та послуги під час обслуговування туристів. В даному випадку не можна не погодитися, що «...непрямий вплив туризму ширше і перевершує по ефективності прямий» [4, С. 17].

За останні два десятиліття показники розвитку туристичної сфери характеризувалися позитивними показниками, розширювалася кількість країнучасників міжнародного туризму, 3 кожним роком зростали масштаби туристичних прибуттів та міжнародних туристичних надходжень. Загальною тенденцією стало щорічний приріст обсягів туристичних подорожей $\mathrm{i}$ щорічне зростання міжнародних туристичних потоків як на регіональних рівнях, так і світовому ринку.

Всебічне дослідження праць дослідників та аналітиків 3 питань розвитку туристичного сектору [5-6; 8; 10-11], дозволило встановити, що наша країна також характеризувалась динамікою позитивних зрушень у галузі внутрішнього та іноземного туризму. Адже вигідне територіальне розташування у центрі Свропи, наявність значних природних ресурсів, сприятливі кліматичноприродні умови, унікальні історико-культурні пам'ятки світового рівня та туристичнорекреаційний потенціал - у сукупності дають Україні численні переваги для конкуренції на міжнародному туристичному ринку.

За ряд останніх років зберігалася позитивна тенденція - щорічне зростання сукупних надходжень туристичного збору та податкових платежів 3 туристичної галузі України. Як зазначалося у дослідженні вітчизняних фахівців туристичної галузі: «Про те, що Україна стає все популярнішою серед іноземних відвідувачів свідчить i те, що $\mathrm{CNN}$, одна 3 найвідоміших телекомпаній світу, склала окремий рейтинг $з$ топ11 туристичних міст України. До нього ввійшли Львів, Чернівці, Умань, Київ, ПереяславХмельницький, Харків, Чернігів, Одеса, Ужгород та
Кам'янець-Подільський. $\mathrm{B}$ Україні $\epsilon$ безліч прекрасних місць 3 великою кількістю туристичних заходів. Жваві міста, стародавні замки, приголомшлива сільська місцевість, різноманітність ландшафтів та гостинність - все це робить Україну особливим місцем...» [3].

Варто акцентувати увагу на тому, що, нажаль, функціонування вітчизняних туристичних підприємств суттєво гальмувалося через: невідповідність наявної матеріальної бази (автодороги, міжнародні транспортні коридори) загальним міжнародним стандартам; неефективний механізм управління туристичною сферою; податкове навантаження (що не сприяє вкладенню інвестицій в інфраструктуру туризму); занедбаність об'єктів туристичної спадщини; низький рівень конкурентоздатності; недостатнє забезпечення туристичної галузі висококваліфікованими фахівцями тощо [4-6; 12; 14].

Істотні корективи у функціонування туристичної сфери на всіх рівнях (глобальному та регіональному) внесли запровадження превентивних заходів щодо протидії пандемії коронавірусу в світі та Україні зокрема. Дійсно, пандемія коронавірусу, розпочавшись у Китаї наприкінці 2019 p. і розповсюдившись на весь світ, із часів Другої світової війни стала найбільшим викликом та загрозою для всіх, без винятку, країни.

Необхідно зауважити, що розгортання політики подолання масштабів поширення коронавірусної інфекції, мінімізації ризиків загострення епідемічної ситуації викликали необхідність закриття кордонів країнами світу. За оцінками фахівців Національного інституту стратегічних досліджень: «96\% туристичних дестинацій у всьому світі зазнали обмежень. Втрати туристичної галузі в Україні оцінюються у понад 1,5 млрд дол. США. Пізній початок курортно-рекреаційного сезону внаслідок впровадження обмежувальних заходів також створив кумулятивний ефект, який негативно вплинув як на індустрію відпочинку та подорожей, так і на супутні галузі - готельно-ресторанний бізнес, транспорт (пасажирські перевезення), роздрібну торгівлю, індустрію розваг та діяльність установ культури» [5, С. 5].

Це вкрай негативним чином відобразилося на в'їзному та виїзному туристичному ринках у глобальному масштабі i функціонуванні туристичної сфери всього світу. Таким чином, невизначеність подальшого розвитку ситуації, виникнення перешкод нормального здійснення подорожей, обмеження на пересування, занепокоєння людства щодо збереження власного здоров'я та безпеки стали причиною кризи та збільшення обсягів збитків туристичних підприємств. 
За оцінками ряду провідних закордонних та вітчизняних економістів, рейтингових агенцій, аналітиків всі країни зіштовхнулися із загрозою глобального масштабу, яка матиме (і вже має) негативні наслідки на розвиток глобальної економічної системи та призведе до скорочення іï темпів. Базуючись на результатах досліджень [8; 12] наведемо основні очікувані негативні наслідки загострення епідемічної ситуації для світової економіки (табл.1).

Таблиця 1

Очікувані негативні наслідки загострення епідемічної ситуації для світової економіки

\begin{tabular}{|c|c|}
\hline $\begin{array}{l}\text { № } \\
\text { 3/ח }\end{array}$ & Наслідки \\
\hline 1 & $\begin{array}{c}\text { В Україні прогнозуються обсяги падіння ВВП до рівня 7,7\%, а рівень безробіття може досягти } 10 \% \\
\text { (прогноз МВФ, квітень } 2020 \text { р.) }\end{array}$ \\
\hline 2 & $\begin{array}{c}\text { Передбачається, що країни світу ймовірно будуть спроможні відновити свій економічний стан вже у } \\
2021 \text { р., але повністю компенсувати негативні наслідки, завдані у } 2020 \text { р., країнами неможливо. } \\
\text { Прогнозується, що міжнародна економіка зможе досягти стану } 2020 \text { р. } \\
\text { лише у } 2022 \text { р. }\end{array}$ \\
\hline 3 & $\begin{array}{c}\text { Прогнозується, що не всі економічні сфери зазнають серйозних негативних наслідків від пандемії. А } \\
\text { найбільш «потерпаючими» стануть економіки тих країн, які прямо залежні від транспортних } \\
\text { перевезень і туризму }\end{array}$ \\
\hline 4 & Імовірні варіанти моделі економічного відновлення представлено двома можливими сценаріями: \\
\hline 4.1 & $\begin{array}{c}\text { - перший сценарій: відновлення як всесвітньої економічної моделі, так і економічних відносин між } \\
\text { країнами відбуватиметься за V-образною схемою, яка передбачає продовження ситуації у стані «як є» } \\
\text { (за прогнозами аналітиків, це найбільш вірогідний варіант для України) }\end{array}$ \\
\hline 4.2 & $\begin{array}{c}\text { - другий сценарій: більш тривалий період кризи (навіть рецесію) зі значними соціальними наслідками, } \\
\text { невизначена тривалість періоду пандемії, обмеження на пересування. Що може призвести до істотних } \\
\text { змін у глобальній соціально-економічній моделі }\end{array}$ \\
\hline 5 & $\begin{array}{c}\text { За даними ЮНВТО (Всесвітня туристична організація - Unated Nations World Tourism Organization) } \\
\text { карантинні заходи у країнах світу призвели до введення обмежень на пересування 100\%-ми усіх } \\
\text { міжнародних дестинацій } \\
\text { (Звіт ЮНВТО від } 29.04 .2020 \text { р.): }\end{array}$ \\
\hline 5.1 & - 97 дестинацій (45\%) повністю або частково закрили свої кордони для туристів; \\
\hline 5.2 & - 65дестинацій (30\%) повністю або частково призупинили здійснення міжнародних авіарейсів; \\
\hline 5.3 & $\begin{array}{c}\text { - } 39 \text { дестинацій (18\%) закривають свої кордони за більш диференційованим принципом, забороняючи } \\
\text { в’їзд для пасажирів із певних країн походження }\end{array}$ \\
\hline 6 & $\begin{array}{c}\text { Світова авіа-індустрія - одна з найбільш постраждалих від коронавірусу. } \\
\text { Припинення рейсів до Китаю, згодом - до Європи, - викликало кризу глобального масштабу у галузі. } \\
\text { За останніми оцінками Міжнародної асоціації авіаційного транспорту (ІАТА), втрати галузі можуть } \\
\text { сягнути } 113 \text { мільярдів доларів. } \\
\text { Загалом, за оцінками ІАТА, міжнародний авіа-бізнес може скоротитися на 19\% }\end{array}$ \\
\hline 7 & $\begin{array}{c}\text { Круїзний бізнес - також постраждав від карантинних обмежень. } \\
\text { Акції Carnival Corporation, якій належить Diamond Princess, а також інших провідних круїзих компаній } \\
\text { (Norwegian, Royal Caribbean) впали на 60-70\% з січня } 2020 \text { р. } \\
\text { Поширеною стала практика відмови круїзним лайнерам у стоянках в портах. } \\
\text { Royal Caribbean скасував } 18 \text { рейсів до Азії (завдало збитків компанії у } 130 \text { млн. доларів). Norwegian } \\
\text { скасувала } 40 \text { рейсів до Азії до кінця } 2020 \text { р. (завдало збитків компанії у } 16 \text { млн. доларів). Carnival } \\
\text { оцінює свої збитки у близько } 440 \text { млн. доларів }\end{array}$ \\
\hline
\end{tabular}

Оперативно відреагувала на виклики пандемії і ЮНВТО, створивши «Глобальний кризовий комітет 3 туризму». Мета створення такого органу полягає у:

- максимальному сприянні у здійсненні урядами країн світу комплексу кроків із підтримки функціонування туристичної сфери;

- розробка та реалізація планів відновлення світової туристичної індустрії;
- підготовка пакету технічної допомоги відновлення («Recovery Technical Assistance Package»).

Складовими структурними Комітету виступили наступні організації (рис.1). 


Глобального

Рис. 1. Організації, що входять до складу

«Глобального кризового комітету з туризму»

Складено автором за [5, С. 7]

Уряди країн світу запроваджують ряд заходів i кроків для забезпечення сталого функціонування туристичної сфери, пристосування до нових жорстких і обмежувальних економічних умов розвитку. Серед найбільш поширених варіантів запровадження політики мінімізації негативних наслідків розгортання пандемії 3 боку урядів виступають: відтермінування сплати податкових, боргових зобов'язань та забезпечення доступних кредитних ліній для суб'єктів підприємництва. Вважаємо за необхідне розглянути приклади застосування заходів підтримки туристичних підприємств у декількох країнах світу [5, С. 8-29; 12 , C. 10-11]:

- Грузія: урядом підготовлено напрями стимулюючої політики відносно туристичного галузі та іiі захисту. Передбачено ряд заходів фіскального характеру, а саме, звільнення від податку на майно та податку на прибуток туристичних підприємств; погашення урядом відсотків за кредити для готелів, із готельними номерами від 4 до 50 одиниць.

- Італія: задля повномасштабного впливу створено навчальні матеріали щодо загроз пандемії, а також затверджені протоколи всім суб'єктам туристичної діяльності. Виділено державне фінансування відновлення кіносектору та фестивального шоу;

- Німеччина: загальнодержавна політика послаблення фіскального навантаження, відстрочка платежів за позиками, підтримка ліквідності. Інформаційна підтримка всіх суб'єктів туристичної діяльності шляхом запровадження роботи веб-сайту (www.corona-navigator.de) iз постійним моніторингом ситуації та рекомендаціями;

- Таїланд: загальнодержавна політика стимулювання туристичної сфери, а саме започаткування «Проекту стимулювання внутрішнього туризму» під егідою Управління туризму Таїланду; «Проекту розвитку потенціалу підприємців та персоналу в туризмі» під егідою Департаменту туризму; «Проект з розробки систем кіберпошуку для запобігання та протидії злочинності, яка впливає на туризм» під егідою Бюро туристичної поліції;

- Угорщина: надання цільової фінансової допомоги найбільш постраждалим секторам (туризм та гостинність); значне посилення заходів соціального захисту для секторів економіки, що перебувають під найбільшою загрозою (подорожі, туризм); запровадження спрощеної процедуру оподаткування та процедури подачі податкових декларацій. Запроваджена практика звітування перед Урядом Угорської агенції туризму щодо стану туристичних підприємств. Також ця організація підготувала пакет антикризових дій щодо туристичного сектору (зокрема, роботодавці цих підприємств звільняються від сплати податку на заробітну плату на відповідний період 2020 р., за винятком внеску на охорону здоров'я);

- Фінляндія: пряме державне фінансування закладів ресторанної сфери, а також фінансова підтримка національної авіакомпанії Finnair. 
В нашій країні уряд також здійснюе ряд заходів, спрямованих на мінімізацію руйнівного впливу карантинних обмежень на всі сфери економічної діяльності. Ці заходи фінансового та нефінансового характеру повинні «пом'якшити» наслідки впливу пандемії на соціально-економічне життя та добробут населення країни. Так, Верховна Рада України 16 червня 2020 p. підтримала у другому читанні проект Закону «Закон про внесення змін до деяких законодавчих актів щодо державної підтримки сфери культури, креативних індустрій, туризму, малого та середнього бізнесу у зв'язку з дією обмежувальних заходів, пов'язаних із поширенням коронавірусної хвороби (COVID-19)» [9]. Президент України 13 липня 2020 р. підписав Законопроект № 3377, що означає реалізацію передбачених антикризових заходів у перелічених сферах економіки України у період карантинних обмежень. Окрім того, КМУ 27 травня 2020 p. затвердив 3 доопрацюванням «Програму стимулювання економіки для подолання наслідків епідемії Covid-19» [13]. Програмою передбачено застосування заходів підтримки для таких секторів, як: сфера послуг (торгівля, готельно-ресторанна справа, освіта, креативні індустрії, особисті послуги); сільське господарство; промисловість; транспорт та інфраструктура; енергетика; інформаційно-комунікаційні технології. I хоча у зазначеному урядовому документі заплановано ряд ініціативних програм регулювання туристичної сфери (впровадження яких може розтягнутися у часі), за оцінками фахівців вітчизняний туризм не отримав відповідної підтримки з боку держави, а це означає, що його стабілізація буде істотно відставати від темпів відновлення туристичних сфер інших країн.

Спираючись на всі вищенаведені факти, можемо стверджувати, що для кожної країни вкрай актуальною $є$ необхідність вжиття низки заходів для мінімізації наслідків карантинних обмежень на діяльність підприємств туристичної сфери. В рамках цього дослідження підкреслюємо важливу тезу, що головним критерієм для відновлення туристичної сфери повинно бути досягнення оптимального балансу між питаннями безпеки, охорони здоров'я та економічними інтересами. I хоча влітку 2020 p. країни ЄC (що мали динаміку поліпшення епідеміологічної ситуації та при збереженні всіх необхідних заходів безпеки для охорони здоров'я) відкривали свої кордони та знімали обмеження на пересування, це не призвело до відновлення попереднього рівня туристичних потоків. Країни, що відкрили свої кордони, ввели обов'язкове вимірювання температури (або проведення тесту на коронавірус) в аеропортах, під час посадки в літаки. Головною проблемою при цьому залишаються два питання: достовірність експрес-тестів на коронавірус та обгрунтування необхідності, за який час до вильоту пасажири повинні пройти тестування. Деякі країни піднімають питання введення для всіх подорожуючих так званих паспортів здоров'я, який буде мати інформацію про наявність імунітету до коронавірусу. Як зазначає у своєму дослідженні $[12$, С. 8$]$, вакцинація та медичні препарати, нажаль, «...дають невелику надію на відновлення економіки у короткостроковій перспективі, особливо що стосується подорожей і туризму».

Для України основними заходами стабілізації туристичної сфери та мінімізації збитків на внаслідок пандемії, на думку автора, можуть виступати (рис.2).

Безперечно, істотним результатом розвитку туристичної сфери України вважаємо затвердження «Дорожної карти конкурентоспроможного розвитку сфери туризму в Україні» (розроблена за підтримки Європейського банку реконструкції $\mathrm{i}$ розвитку наприкінці 2019 р.). Цей документ свого часу базувався на динаміці стрімкого розвитку світової туристичної сфери в умовах стабільного зростання глобальної економіки. А тому повинен бути доповнений заходами, що спрямовані на подолання дестабілізації світової економіки та функціонування туристичної сфери, зокрема. Такими доповнюючими заходами можуть виступати:

- «ініціювання визначених у Дорожній карті процесів із реорганізації для туристичної статистики, управління туризмом i нормативноправової системи, що $є$ найпроблемнішим питанням у туризмі (закони, постанови та збірки правил)»;

- «субвенції, доступні кредитні лінії, звільнення від податкових і боргових зобов'язань із метою збереження основної частини галузі»;

- «впровадження та внутрішне просування добірки правил роботи для різних об'єктів розміщення та кейтерингу» $[12$, С. 21$]$.

\section{Висновки}

Вважаємо за необхідне зазначити, що сьогодні не викликає сумнівів необхідність активізації процесів та заходів щодо подолання згубного впливу пандемії на туристичну сферу вітчизняної економіки. Наголошуємо, що загальнодержавна реалізація всіх антикризових важелів, системність та послідовність в реалізації всіх заходів сприятиме якнайшвидшій їх стабілізації розвитку суб'єктів туризму та досягнення ними рівня економічної ефективності діяльності.

На думку автора, предметом наших подальших наукових досліджень можуть виступати обгрунтування цифрової трансформації процесів 
функціонування туристичної сфери, як одного 3 напрямів іiї стабілізації.

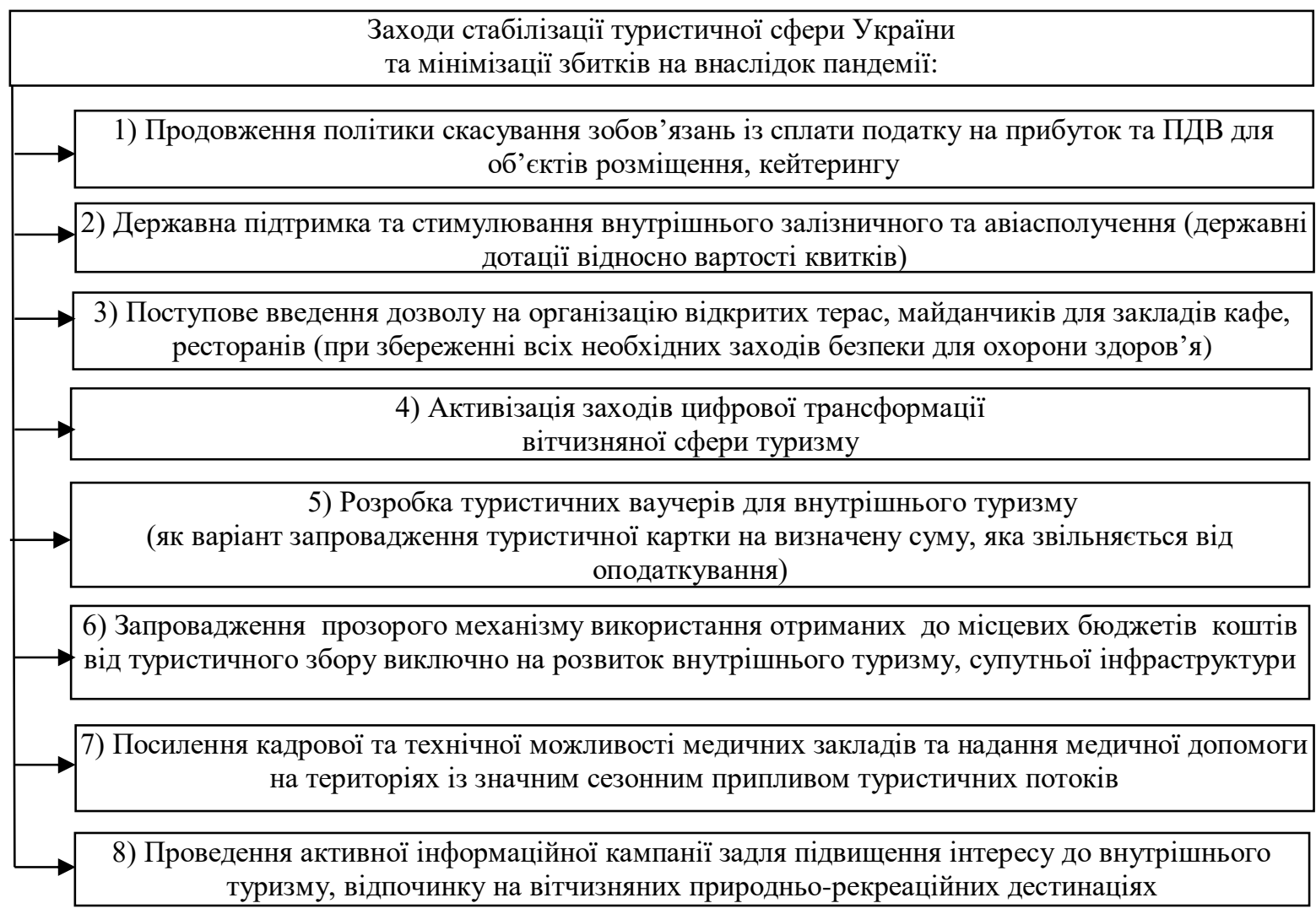

Рис.2. Рекомендовані заходи стабілізації туристичної сфери України та мінімізації збитків на внаслідок пандемії

\section{Література}

1. Ворошилова, Г.О. Розвиток міжнародного ринку туристичних послуг в умовах кризи. Науковий вісник Херсонського державного університету. Серія: Економічні науки. 2014. Випуск 7. Частина 1. С.75-78.

2. Гоблик-Маркович, Н.М., Ільтьо, T.I. Аналіз динаміки та актуальних проблем розвитку сфери туризму. Міжнародний науковий журнал «Освіта і наука». 2018. Випуск 24(1). C.16-22.

3. Горбань, Ю. До речі, в туризмі Украйна не пасе задніх. URL: https://www.ukrinform.ua/rubric-society/2664756-doreci-v-turizmi-ukraina-ne-pase-zadnih.html (дата звернення: 21.09.2020).

4. Горіна, Г.О. Розвиток ринку туристичних послуг України в умовах просторової поляризації: дис...д.е.н. за спеціальністю 08.00 .03 - економіка та управління національним господарством. Дніпро: Донецький національний університет економіки $i$ торгівлі імені Михайла Туган-Барановського, Вищий навчальний заклад «Університет імені Альфреда Нобеля», 2017. 493 с.

5. Жаліло, Я.А., Ковалівська, С.В., Филипенко, А.О., Химинець, В.В., Головка, А.А. Щодо розвитку туризму в україні в умовах підвищених епідемічних ризиків: Аналітична записка Національного інституту стратегічних досліджень. Київ, 2019. 29 с.

6. Заворуєва, О.С.Удосконалення стратегії управління розвитком туристичної галузі України. дис...к.е.н. за спечіальністю 08.00 .03 - економіка та управління начіональним господарством. Класичний приватний університет, Запоріжжся, 2019. 205 c.

7. Заворуєва, О.С. Науково-практичні рекомендачії щзодо удосконалення стратегії розвитку туристичної галузі України. Причорноморські економічні студіï. 2017. Вип. 15. Ч. 1. C. 251-255.

8. Зануда, А. Коронавірус: скільки втрачає туризм. URL: https://www.bbc.com/ukrainian/features-51870285 (Dama звернення: 21.09.2020).

9. Закон України «Про внесення змін до деяких законодавчих актів щзодо державної підтримки сфери культури, креативних індустрій, туризму, малого та середнього бізнесу у зв'язку з дією обмежувальних заходів, пов'язаних із поширенням коронавірусної хвороби (COVID19)» від 22.04.2020 p. № 3377. URL: http://search.ligazakon.ua/__doc2.nsf/link1/info/JI01905A.htm l (дата звернення: 21.09.2020).

10. Захарін, С. Організачійно-економічні чинники розвитку сфери туризму та курортів в Украӥні. Вісник Київського національного університету культури $i$ мистеитв Серія: Туризм. 2018. № 2. С.57-66.

11. Оболенцева, Л.В., Галииька А.М. Оиінювання впливу туризму як економічного явища: Сучасні тенденції розвитку індустрії туризму та гостинності $y$ конкурентному середовищі: матеріали міжнародної науково-практичної конференції, м. Харків / колектив авторів; Харківський наиіональний університет міського господарства імені О.М. Бекетова, 2020. - 232 с.

12. Пандемія COVID-19 та ї̈ наслідки у сфері туризму в Украӥні (Оновлення до документу «дорожня карта 
конкурентоспроможного розвитку сфери туризму в Україні»). URL: https://ntoukraine.org (дата звернення: 21.09.2020).

13. Постанова КМУ від 27.05.2020 р. «Програма стимулювання економіки для подолання наслідків епідеміі Covid-19». URL: https://www.kmu.gov.ua/news/uryadzatverdiv-z-doopracyuvannyam-programu-stimulyuvannyaekonomiki-dlya-podolannya-naslidkiv-epidemiyi-covid-19 (дата звернення: 21.09.2020).

14. Шацька, 3.Я., Акульшин, М.І. Актуальні проблеми та перспективи розвитку сфери туризму в Україні. Економіка і суспільство. 2018. Випуск 19. С.699-705.

\section{References}

1. Voroshilova, G.O. (2014) Development of the international market of tourist services in the conditions of crisis. Scientific Bulletin of Kherson State University. Series: Economic Sciences.. Issue 7. Part 1. P.P.75-78.

2. Goblik-Markovich, N.M., Iltio, T.I. (2018) Analysis of the dynamics and current problems of tourism development. International scientific journal «Education and Science». Issue 24 (1). P.P.16-22.

3. Gorban, Yu. (2019) By the way, Ukraine does not lag behind in tourism. URL: https://www.ukrinform.ua/rubricsociety/2664756-do-reci-v-turizmi-ukraina-ne-pase-

zadnih.html (access date: 21.09.2020).

4. Gorina, G.O. (2017) Development of the market of tourist services of Ukraine in the conditions of spatial polarization: dis... d.e.n. in the specialty 08.00.03 - economics and management of the national economy. Dnipro: Mykhailo Tuhan-Baranovsky Donetsk National University of Economics and Trade, Alfred Nobel University. 493 p.

5. Zhalilo, Ya.A., Kovalivska, S.V., Filipenko, A.O., Khiminets, V.V., Golovka, A.A. (2019) Regarding the development of tourism in Ukraine in conditions of increased epidemic risks. Analytical note of the National Institute for Strategic Studies. Kyiv, 2019. 29 p.

6. Zavorueva, O.S. (2019) Improving the strategy for managing the development of the tourism industry of Ukraine. dis... Ph.D. in the specialty 08.00.03 - economics and management of the national economy. Classical Private University, Zaporozhye. $205 \mathrm{p}$.

7. Zavorueva, O.S. (2017) Scientific and practical recommendations for improving the development strategy of the tourism industry of Ukraine. Black Sea Economic Studies. Vol. 15. Ch. 1. S. 251-255.

8. Zanuda, A. (2020) Coronavirus: how much tourism loses. URL: $\quad$ https://www.bbc.com/ukrainian/features-51870285 (access date: 21.09.2020).
9. Law of Ukraine «On Amendments to Certain Legislative Acts Concerning State Support in the Sphere of Culture, Creative Industries, Tourism, Small and Medium Business in Connection with Restrictive Measures Related to the Spread of Coronavirus Disease (COVID-19)» 22.04.2020 № 3377. URL: http://search.ligazakon.ua/_doc2.nsf/link1/info/JI01905A.htm $l$ (access date: 21.09.2020).

10. Zakharin, S. (2018) Organizational and economic factors of development of tourism and resorts in Ukraine. Bulletin of Kyiv National University of Culture and Arts Series: Tourism. Vol. 2. P.P. 57-66.

11. Obolentseva, L.V., Galitska, A.M. (2020) Assessment of the impact of tourism as an economic phenomenon: Modern trends in the tourism industry and hospitality in a competitive environment: materials of the international scientific-practical conference, Kharkiv / team of authors; Kharkiv National University of Municipal Economy named after O.M. Beketova, $232 \mathrm{p}$.

12. COVID-19 pandemic and its consequences in the field of tourism in Ukraine (Update to the document «Roadmap for competitive development of tourism in Ukraine"). URL: https://ntoukraine.org (access date: 21.09.2020).

13. Resolution of the Cabinet of Ministers of 27.05.2020 «Economic stimulus program to overcome the consequences of the Covid-19 epidemic». URL: https://www.kmu.gov.ua/news/uryad-zatverdiv-z-

doopracyuvannyam-programu-stimulyuvannya-ekonomiki-

dlya-podolannya-naslidkiv-epidemiyi-covid-19 (access date: 21.09.2020).

14. Shatskaya, Z.Y., Akulshin, M.I.(2018) Current problems and prospects for the development of tourism in Ukraine. Economy and society. Issue 19. P.699-705.

Рецензент: д.е.н., професор, завідувач кафедри «Туризму i готельного господарства» Л.В. Оболенцева, Харківський національний університет міського господарства імені О.М. Бекетова, Україна

\section{Автор: СВІТЛИЧНА Вікторія Юріївна}

к.е.н., доцент кафедри «Туризму $i$ готельного господарства»

Харківський національний університет міського господарства імені О.М. Бекетова

E-mail-0972657558.v@gmail.com

ID ORCID: http://orcid.org/0000-0002-5135-0006

\title{
TOURIST SPHERE: SEARCH FOR WAYS TO OVERCOME THE CRISIS IN THE CONDITIONS OF GLOBAL QUARANTINE RESTRICTIONS
}

\author{
V. Svitlychna
}

O.M. Beketov National University of Urban Economy in Kharkiv, Ukraine

The issues of activity of enterprises of the tourism sector in conditions of quarantine restrictions are investigated. The thesis about the relevance of developing a number of anti-crisis measures that would help stabilize the development of these enterprises is substantiated.

The aim of this work is to study the issues of stabilizing the functioning of enterprises in the tourism sector under quarantine conditions. 
The article presents the thesis that the tourism industry is considered one of the most dynamic industries in the world economy and international trade in services. In the modern world, tourism is economic activity related to the movement of a person outside the permanent place of residence, his recreation with health improvement, raising the level of culture and education.

The author of the article states that over the past two decades, the indicators of the development of the tourism sector have been characterized by positive indicators, the number of countries participating in international tourism has expanded, and the scale of tourist arrivals and international tourist receipts has grown every year. Unfortunately, the coronavirus pandemic has made significant adjustments to the functioning of the tourism sector at all levels (global and regional). Indeed, the coronavirus pandemic, which began in China at the end of 2019 and spread throughout the world, has become the biggest challenge and threat to all countries since World War II. The article substantiates that this negatively affected the inbound and outbound tourism markets on a global scale. Thus, the uncertainty of the further development of the situation, the occurrence of obstacles to the normal implementation of travel, restrictions on movement, the concern of mankind to preserve their own health and safety have caused the crisis and an increase in the volume of losses of travel companies.

The focus of the article is concentrated on the analysis of the negative consequences of the aggravation of the epidemic situation for the world economy.

The article emphasizes that for each country it is extremely important to take a number of measures to minimize the consequences of quarantine restrictions on the activities of tourism enterprises. Within the framework of this study, the author emphasizes that the main criterion for the restoration of the tourism sector should be the achievement of an optimal balance between security, health and economic interests.

The article proposes recommended measures to stabilize the tourism sector in Ukraine and minimize losses as a result of the pandemic. The complex of such measures includes:

- continuation of the policy of canceling the obligations to pay income tax and VAT for accommodation facilities, catering; tickets);

- government support and stimulation of domestic rail and air traffic (government subsidies for the cost of

- gradual introduction of permission to organize open terraces, sites for cafes, restaurants (while maintaining all the necessary safety measures for health protection);

- activation of measures for digital transformation of the domestic tourism sector;

- introduction of a transparent mechanism for the use of funds received in local budgets from the tourist tax exclusively for the development of domestic tourism and related infrastructure.

The authors emphasize that today there is no doubt about the need to activate the processes and measures to overcome the harmful effects of the pandemic on the tourism sector of the domestic economy. We emphasize that the nationwide implementation of all anti-crisis levers, consistency and consistency in the implementation of all measures will contribute to their speedy stabilization of the development of tourism entities and their achievement of the level of economic efficiency of their activities.

Keywords: tourism, tourist flows, quarantine, epidemic risks, pandemic, Covid-19, "Roadmap for the competitive development of tourism in Ukraine», development of the tourism sector. 